\title{
Redesign of an Outdoor Space in a Swedish Preschool: Opportunities and Constraints for Sustainability Education
}

\author{
Birgitta Nordén $^{1}$ (D) Helen Avery ${ }^{2,3}$ (D)
}

Accepted: 24 November 2020 / Published online: 4 December 2020

(c) The Author(s) 2020

\begin{abstract}
Children's early engagement in design of outdoor spaces can form the basis of later attitudes and responsible action for sustainability. The present study is part of a participatory action research project in an urban multi-ethnic preschool in Sweden, involving children, parents, preschool staff and management with a focus on improving the preschool playground. The methodology involved children taking pictures of the outdoor space, informal participant observation by one researcher and conversations with children and teachers. Analyses completed of selected fieldwork excerpts focus on learning opportunities for children and adults, children's participation, cooperation and leadership for sustainability. Deeper awareness and confidence, and practical pedagogies for staff in preschools are required for effective sustainability education. A joint frame of reference on pedagogical practices and processes for reflection is needed within and across early childhood institutions. More continuous training of staff and preschool leadership would be of benefit. However, such commitment is ultimately a matter of policy to invest in giving preschools the means to develop and realise ambitions for environmental and sustainability education.
\end{abstract}

Keywords Early childhood education - Environmental and sustainability education (ESE) · Immigrant children · Participatory action research (PAR) · Preschool

\section{Résumé}

L'engagement précoce des enfants dans la conception des espaces extérieurs peut constituer une base d'attitudes ultérieures et d'action responsable en faveur de la durabilité. La présente étude fait partie d'un projet de recherche-action participa-

Birgitta Nordén

birgitta.norden@mau.se

1 Department of Science, Mathematics and Society, Faculty of Education and Society, Malmö University, Nordenskiöldsgatan 10, 21119 Malmö, Sweden

2 Centre for Middle Eastern Studies and Centre for Environmental and Climate Research, Lund University, Lund, Sweden

3 Department of Languages, Faculty of Arts and Humanities, Linnaeus University, Kalmar, Sweden 
tive (RAP) dans un établissement préscolaire multiethnique urbain en Suède, où les enfants, les parents, le personnel et la direction sont impliqués dans un objectif d'amélioration du terrain de jeux de leur maternelle. La méthodologie utilisée fait appel à des prises de photos de l'espace extérieur par les enfants, une observation informelle des participants par une personne de la recherche et une discussion avec les enfants et les enseignants. Les analyses réalisées sur des extraits sélectionnés de travaux de terrain sont centrées sur: les occasions d'apprentissage pour les enfants et les adultes, la participation des enfants, et la coopération et le leadership des adultes envers la durabilité à l'intérieur des institutions et entre celles-ci. Une éducation efficace à la durabilité exige une sensibilisation et une confiance plus profondes, ainsi que des pratiques pédagogiques chez le personnel des établissements préscolaires. Un cadre de référence commun sur les pratiques pédagogiques et les processus de réflexion est nécessaire à l'intérieur et entre les établissements de la petite enfance. Il serait bénéfique d'assurer davantage de formation professionnelle continue chez le personnel, y compris pour la direction d'établissements préscolaires. Toutefois, de tels engagements relèvent en fin de compte des politiques d'investissement pour donner aux établissements préscolaires les moyens d'établir et de réaliser leurs ambitions en matière d'éducation à l'environnement et au développement durable.

\section{Resumen}

La participación temprana de los niños en el diseño de espacios al aire libre puede formar la base de actitudes posteriores y acciones responsables para la sostenibilidad. El presente estudio es parte de un proyecto de investigación de acción participativa (PAR) en un preescolar urbano multiétnico en Suecia, que involucra a niños, padres, personal de preescolar y gerencia con un enfoque en la mejora del patio de recreo preescolar. La metodología implicó que los niños tomaran fotografías del espacio al aire libre, la observación participante informal por parte de un investigador y conversaciones con los niños y los maestros. Los análisis completados de extractos de trabajos de campo seleccionados se centran en las oportunidades de aprendizaje para niños y adultos; participación de los niños; cooperación y liderazgo para la sostenibilidad. Se requiere una mayor conciencia y confianza, y pedagogías prácticas para el personal de los centros preescolares para una educación sustentable efectiva. Se necesita un marco de referencia conjunto sobre prácticas y procesos pedagógicos para la reflexión dentro y entre las instituciones de la primera infancia. Sería beneficioso una formación más continua del personal y del liderazgo preescolar. Sin embargo, dicho compromiso es, en última instancia, una cuestión de política para invertir en brindar a los centros preescolares los medios para desarrollar y realizar ambiciones de educación ambiental y de sostenibilidad.

\section{Introduction}

The present study focuses on an outdoor education project at a Swedish urban preschool for 3-5-year-olds that receives a large proportion of newly arrived children. It draws on data from a larger study at the preschool, informed by participatory action 
research (PAR) (Kemmis 2009; Kemmis et al. 2014). The study examines the collaborative work of the preschool staff and children to improve the preschool playground, to gain a better understanding of conditions for environmental and sustainability education (ESE) using this outdoor space and the various factors that influence the process. The research focuses on the action and interactions that took place during the work on redesigning the playground at the preschool, as well as the children's participation in these processes (Christensen 2004; Heft and Chawla 2006). It considers the implications for early sustainability education and for participatory research in preschool contexts, including adults' interactions with children during the redesign process.

The aims for preschool education are set out in the Swedish national curriculum and preschool teachers are required to organise activities and the spaces in which the activities take place to achieve detailed and specific objectives. Outdoor education is not directly described in the curriculum and learning objectives fall under other headings, such as 'science' (Lpfö 98 revised 2016; 2018, p. 8) or getting to know the immediate environment as an element of identity formation (see Little and Derr 2018). While sustainability is an objective at all levels of Swedish education, the curriculum does not clearly specify how it should relate to learning objectives in other knowledge domains. With respect to sustainability education for younger children, Björneloo (2007) found that the elements the elements that Swedish preschool teachers thought would give the children the best prospects for a sustainable future are: a sense of comprehension and coherence, participation and responsibility, empathy and understanding, self-esteem and communication.

Although the pedagogical stance described by Björneloo (2007) is in line with research on the role of early years education for sustainability, it does not immediately match the ambitious science teaching objectives of the new preschool curriculum. An additional challenge for the educational development of the staff is that there is little information on relevant teaching activities anchored in contemporary research to draw on, and there is a lack of knowledge of how to explore what meaning-making processes look like when critical actions are privileged (cf. Hedefalk 2014). The curriculum's emphasis on knowledge can come into conflict with traditional preschool perspectives on child development, curiosity and play. There is, therefore, a risk of working with fragmented and decontextualised activities that are easy to implement in practice and fit into existing routines (Tuck and McKenzie 2015; Jørgensen and Martiny-Bruun 2019).

\section{Pedagogical Approaches in Swedish Outdoor Environmental Education}

In Sweden, preschool is an integrated part of the education system with its own syllabus and learning targets (SNAE 2017, p. 9). Policy ambitions are rising, and the curriculum therefore creates challenges for preschool teachers, especially in preschools that have not previously focused on nature or science phenomena.

Although sustainability is one of the overarching goals of the Swedish education system, relatively little attention has been paid to how education for sustainability can be achieved through teaching practices, and sustainability goals compete 
with long lists of learning objectives focused on other aims. Also, initial preschool teacher education has not sufficiently equipped practitioners with pedagogical perspectives that can underpin teaching activities and the design of learning contexts for sustainability.

Typical sustainability content and activities in Sweden include disparate elements such as socialising children into practising recycling (Jordt Jørgensen et al. 2018) or learning about 'cycle-thinking' to gain an understanding of how diverse phenomena are interconnected in the natural world (Wells 2014). As in many other countries, sustainability issues are mostly understood as concerning 'nature' (Stephenson 2002), and the responsibility for ESE is consequently placed within environmental education and science. Teaching for scientific literacy occupies a central position in the new curriculum for the preschool, which entered into force in July 2019 (Lpfö 98 revised 2016; 2018, p. 8).

In Sweden, and the Nordic countries generally, 'love of nature' is an important element of education (Jansson et al. 2014) and children are expected to learn the names of local birds, animals and plants (Frisch et al. 2010; Spannring 2017). There is also a long tradition of outdoor education in the Nordic countries (Hammarsten et al. 2019), including excursions to 'natural' sites. Another related area is the notion of green schoolyards' (Jansson and Mårtensson 2012), as well as gardening as a widespread educational practice (MacQuarrie et al. 2015). More recently, children's experiences-or lack of opportunities for experiences of nature (Askerlund and Almers 2016) — in urban contexts have again become the object of pedagogical discussions, notably concerning the way such contexts affect children's understanding of self (Cele 2006; Blundell 2016; Little and Derr 2018) and how children relate to non-human life forms (Pedersen 2019). In Sweden and elsewhere, lack of opportunities for young children to access nature or green environments, particularly in lowincome urban contexts, has led to the development of 'forest schools' (Knight 2009) and similar initiatives.

A place-based approach and how the children are positioned in the spaces of the preschool is particularly interesting with respect to Swedish early education, since the curriculum specifies that children should get to know their immediate surroundings. Smith (2002) summarises the value of place-based education as 'learning to be where we are' (p. 593). Woodhouse and Knapp (2000) underline the potential of place to connect the individual, community and environment, while Sobel (2020) additionally emphasises the opportunities place-based environmental education offers to look closely at aspects of a local environment and acquire a sense of environmental responsibility. The present study concerns a preschool with many newly arrived children, for whom getting to know their surroundings is important not only as a conventional element of outdoor education for sustainability but also in relation to supporting children's agency and the opportunities the children are given to position themselves in Swedish society outside their homes (Bergsten and Larberg 2012; Jordt Jørgensen and Martiny-Bruun 2019; Little and Derr 2018; Sobel 2020).

Different and sometimes conflicting aims and perceptions of childhood can underlie pedagogical approaches to the design of outdoor facilities in early childhood education. The sociology of childhood (James and Prout 1997) emphasises children's capability and agency (Heft and Chawla 2006; Caiman and Lundegard 
2014; Schiller and Einarsdottir 2009). Such pedagogies are in line with the tradition of Reggio Emilia (Meier and Sisk-Hilton 2017) that sees children as inquisitive and capable learners, but contrasts with traditional 'fact-based' pedagogies which aim to shape the child and transfer knowledge (Öhman 2008). In the Swedish literature, inquiry-based education occupies a middle position in this spectrum. Thus, Andersson and Gullberg (2014) identify four fundamental skills for teaching science in preschools:

1. paying attention to and using children's previous experiences,

2. capturing unexpected things that happen at the moment they occur,

3. asking questions that challenge the children and stimulate further investigation,

4. situated presence, that is, 'remaining' in the situation and listening to the children and their explanations.

Similarly, for science learning in preschool, Hansson et al. (2014) recommend identifying and building on children's questions and everyday situations, arguing that children should be given opportunities to investigate and search for answers.

The various understandings of childhood have implications for early sustainability education, leading to different degrees of emphasis on the child's development as a person, on providing opportunities to discover and relate to the natural world or on learning concepts and facts that prepare the child for school (Sanders 2003). Inversely, from the perspective of ESE, early childhood is a particularly important period since it strongly affects both how we understand and experience the world, and the extent to which we see ourselves as capable of making a change in the world. Research suggests that early childhood experiences of nature shape emotional relations to the natural environment, supporting agency and environmental awareness (Hackett et al. 2017; Hammarsten et al. 2019). Outdoor education thus lays the foundation for future engagement with and education for sustainability.

\section{The Current Study}

Against the background presented, this study looks at how preschool staff, together with the children and other actors, conducted the process of redesigning the outdoor space of the preschool. Two situations are described and analysed to illustrate some of the significant aspects of the redesign process in relation to sustainability and children's engagement.

The research approach in the overarching project Opening up new spaces for preschool education in a diverse and migrating world, from which the data are drawn for this research report, took place from 2017 to 2019. It drew on participatory action research (PAR) and aimed to enhance the participating preschool practitioners' understanding of their practice, as well as to gain a clearer picture of the structural and organisational conditions for their work.

The overall project used a participatory approach, with the notion of "practice architectures' (Kemmis 2009, pp. 466-467) as a lens in the analysis. Kemmis et al. (2014) argue that in school-community projects, by thinking, acting and relating 
to one another differently, people can enable themselves to change their practice collectively. By reflecting together on the conduct of a practice, its character and consequences, new communicative spaces can be opened up. In the overall project, emphasis was placed not only on participation, but on creating opportunities for meetings across organisational hierarchies between people who otherwise may not have met.

\section{Methodology}

This sub-study in the overall project focused on the collective redesign of a preschool playground and took place from Spring 2018 to Summer 2019. The study was approved by the regional ethics board; informed consent was obtained from parents, and the research in this project was conducted in accordance with ethical guidelines in Sweden (Swedish Research Council CODEX [n.d.]). Special care was taken throughout to involve the children in the research process in a respectful and inclusive manner (Flewitt 2005). This sub-study involved two researchers. One researcher teaches sustainability education modules to preschool teachers, works with continuous education of teachers concerning sustainability and also has a long experience with greening schoolyards. The other researcher has worked with participatory methodologies in organisational development and has researched forest gardens used in education of primary school pupils.

\section{Research Context}

The staff of the preschool is ethnically diverse, but very few have any background relating to sustainability and outdoor education. The children's backgrounds were also very diverse, but very few came from rural areas. Particularly for the newly arrived children, the preschool outdoor space was the only outdoor environment they had regular access to. Families often lived in cramped conditions and frequently had to change accommodation. Parents were not only unfamiliar with the opportunities and outdoor spaces of the city, but also had little time to go out, since they were fully occupied with work, language courses and the numerous administrative tasks that moving to a new location involves.

The preschool is located in a multi-ethnic urban area. The busy and somewhat insecure nature of the area has led to certain measures to shield the playground from the urban space of the street. The preschool outdoor space is also shared with the inhabitants of the block of apartments in which the preschool occupies most of the ground floor, which means that any changes to the outdoor space also needed to be negotiated with the manager of the apartments and the inhabitants of the building.

The emphasis in the larger study was focused mainly on one section at the preschool, with about 20 newly arrived children who did not speak any, or very little Swedish, while the outdoor project described in this study involved all three sections of the preschool. Cooperation between the three sections of the preschool was initiated through a 'child council' ( $n=4$ children) and the teachers' outdoor group 
( $n=5$ : staff + researcher), focusing on ways to change the preschool playground and create an outdoor environment offering rich opportunities for play and learning. The meetings for this outdoor project took place regularly, involving children and staff. The children were actively involved in the designing phase (see Heft and Chawla 2006), and the children's council contributed with suggestions from children in their section.

\section{Data Collection}

Throughout the process, the researchers had conversations in groups with staff or with staff together with managers, as well as individual interviews with parents. The first author collected most of the data relating to the outdoor project and participated in the outdoor group meetings. Five preschool teachers were interviewed, to explore their perspectives and the children's perspectives (Christensen 2004; Schiller and Einarsdottir 2009) on what are important activities in science/ESE.

The children took pictures of the outdoor space during the project. Some preschool teachers worked on this part of the project and let the children go out together (four at a time) to photograph what they wanted (Einarsdóttir 2005; Hammarsten et al. 2019). During the term that followed, the teachers and the children worked with the photographs as narrative and image-making (cf. Tuck and McKenzie 2015; Magnusson 2017). The study also involved informal participant observation and conversations with children (Green 2012) during the work that took place in the preschool outdoor area.

\section{Data Analysis}

The focus of this study was on adult-child interaction and opportunities for children's engagement during the outdoor work, when suggestions for changes in the space were being implemented. All field notes were read several times. In the regular meetings among the preschool staff and meetings where researchers participated, two of the main issues identified by the staff were firstly, how to translate into practice the ambition of actively engaging the children and secondly, organisational constraints during the transformation of the playground. To support staff reflection on these issues, two situations were selected by the authors: one to illustrate the typical interactions and activities during this work and the other to illustrate how contributions by actors outside the preschool translated into practice. In the analysis of the field notes, the literature on outdoor and environmental pedagogies was used to identify and discuss which opportunities for engagement the situations offered. The rich material collected during the process was used as a background to inform the analysis of the field note excerpts for these two situations. To validate the analysis, interpretations of the significance of the observed situations and the interactions that took place were discussed with the preschool staff in smaller meetings during the process.

In a second step, based on observations and staff interviews, we extended our gaze to reflect on how the outdoor project affected children's engagement during the 
indoor activities (see Stephenson 2002; Jordt Jørgensen and Martiny-Bruun 2019). Finally, opportunities and obstacles for PAR in the present sub-study were considered within the overall findings from the larger project, including issues of preschool organisation and management. Both interpretations of the situations described below, and the more general findings were discussed in detail and validated during a meeting with all staff at the end of the project.

To illustrate the findings, examples and excerpts from field notes will be provided from two phases of the project. The first concerns the launching phase in Spring 2018, when decisions were made on which changes children and adults wanted to see in the outdoor space and the first steps were taken in transforming the space. The second phase concerns the involvement of Pedagogical Inspiration in the Autumn 2018 installing a ready-made 'ecosystem' in the outdoor space. Pedagogical Inspiration is a department of the municipality that is responsible for supporting educational development and research on educational practice. Staff from Pedagogical Inspiration visited the preschool a couple of times during the autumn and provided the playground with a large larkwood box, which later in the autumn was equipped with a meandering serpentine water channel and a water pump. A water tap was also connected to the outdoor water system, thanks to the support of the manager of the apartment building in which the preschool was located. This was appreciated by the preschool teachers and children since water play opportunities outdoors had long been on the children's wish list.

\section{Findings}

In this section, the findings from the analyses of two situations in the project are presented. Findings are reported in four sections: learning opportunities for children and adults; children's participation; cooperation and leadership towards sustainability; and reaching beyond the outdoor space. The analyses give consideration to Andersson and Gullberg's (2014) ideas on the importance of the interactions and actions of adults and children, building on children's previous experiences, capturing in-the-moment experiences and listening to children Additionally, this project focused on staff experiences and engagement to learn and gain new skills about ESE pedagogies.

\section{Learning Opportunities for Children and Adults}

The outdoor project was initially developed by one preschool teacher, assisted by two other preschool teachers and one researcher, through a morning time session with the children sitting gathered in a circle. After a brief introduction, the researcher was given the floor and walked around and showed to each child three species of plants (cf. Frisch et al. 2010). The first plant, wild strawberries, had berries to taste and eat; the second plant, lamb's-ear, had smooth leaves to touch; and the last plant, woodruff, had a nice fragrance of musk. All three were to be planted by the children, and the emphasis during the morning gathering was to inspire the children to 'work' with the outdoor environment. 
Under the instruction of one of the preschool teachers, all the children went out to put seeds and the plants in the soil and do some watering. A few kids happily helped carrying the buckets with the plants to some prepared boxes on the school ground. There, they stood in a queue to do their part of the 'work,' sensing with their bare hands the warm and smooth soil, while packing it under great enthusiasm and joyfully planting seeds and wedges/plants. Each child had their turn to enter the cultivation box and water it with a small watering can. Then, most of them left the spot and ran away to play on the common playground, while a few lingered on to happily talk to the researcher about their experience of this activity (field notes, Spring 2018).

The observations during this outdoor activity day that had been organised to launch the project could be compared with the definition of education in preschool made by Pramling Samuelsson (2017), which stresses interaction and negotiation of meaning. With respect to education for sustainability in particular, participation and responsibility for increased understanding of how one's own actions impact the environment form a foundation of conscious choice-making (Björneloo 2007). Empathy and understanding are needed to create a sustainable society (Askerlund and Almers 2016). Children need to reflect on what rights and responsibilities mean to them and others and on the ways in which different perspectives may conflict. Across the observed situations, there were multiple opportunities to talk to the children about how actions impact the environment, to think about responsibility and also to discuss possible conflicts between different people's desires and intentions. Such opportunities were seldom seized and there was little communication for collaboration or communicative action (Kemmis et al. 2014).

Most of the staff had limited training in environmental education, so they sometimes struggled to answer questions that they were not prepared for. This may have resulted from not knowing about the phenomena or not seeing these questions and situations as learning opportunities. Nevertheless, the activities around redesigning the playground aroused interest and curiosity among the staff:

Microexample adult interaction: Two educators from Pedagogical Inspiration, one of the preschool staff and the researcher were working outside with the project. A preschool teacher (one of three in the 'Outdoor group'), who had indoor tasks at this moment, asked the researcher what plants are being planted in the larkwood box, which was worked on by the Pedagogical Inspiration staff for a few hours. The researcher answered and described the plants' characteristics (field notes, Autumn 2018).

Generally, the teachers seemed more confident in situations of planned activities that they had already tried out, in which their own role and expected outcomes were foreseeable. It was harder for them to manage the new opportunities offered by the process of redesigning the outdoor space, which did not necessarily correspond to established routines. Often, staff time was taken up by designated routines and responsibilities, and it was difficult to focus on a particular child or group of children when the teacher was supposed to keep an eye on all the other children outdoors at 
that time. In some instances, lack of engagement in conversations with children may have resulted not only from lack of time, but from insufficient critical knowledge capability (cf. Lpfö 98 2018; Nordén 2016).

\section{Children's Participation}

Generally, the children were happy, curious and excited about the changes in the outdoor environment. However, the focus among the adults from the Pedagogical Inspiration team and the preschool educators was getting the work done quickly, rather than adding extra time and space for communication and engagement with the children (see Nordén 2016). Participatory experiences with action outcomes were rare and the adults showed limited interest and curiosity to listen to what the children might be thinking during the activities (Schiller and Einarsdottir 2009; Green 2012). The significance of the experiences and observations that the children made during the work was not commented on in adult interactions with the children. A certain tension could also be recognised between the children's own curiosity and wish to take command versus the teachers' expressed demand for specific participation in selected activities (see Björneloo 2007; Hedefalk 2014).

Above the cultivation box, some tree branches with low hanging green heartshaped leaves caught the attention of some curious children and were explored. They jumped up to grasp the leaves with their hands to play with, but the preschool teacher warned them not to touch since the trees belonged to the garden of a neighbourhood institution. The trees behind a fence were considered to be protected as a cultural/natural memorial of the municipality (field notes, Spring 2018).

Although the children's council had been part of the designing process, during the installation of the 'ecosystem' box, several opportunities were missed to involve the children. Staff from Pedagogical Inspiration brought many types of plants and berry bushes and a large amount of soil (50 sacks full), and finalised most of the preparations with the installation of the ecosystem project (the box with its content) in half a day. The job was almost completed in one day together with one preschool teacher and one PAR researcher (not only observing but actively working with the others).

Several of the children were curious, but only a few took part actively, while other preschool teachers continued their ordinary outdoor tasks. One staff member shared nostalgic memories from grandparents gardening in the past (cf. Sobel 2020). Another staff member played music from an open window before the children went indoors for an afternoon meal. One girl actively dug the soil, mixed it with sand and planted wild strawberries. Three boys had earlier been appointed to another spot of the school ground in which they dug in the soil for worms, to show the teacher and the researcher while carrying them in small buckets (field notes, Autumn 2018).

Some of the kids seemed curious and wanted to speak with the adults involved in improving the preschool's playground. They looked, got closer and seemed 
to want to know what was going on and try to get involved (field notes, Autumn 2018).

Ultimately, the redesign of the outdoor space led to a richer environment, and the opportunities it offered were later used by the children for both spontaneous exploration and teacher-led activities.

\section{Cooperation and leadership towards sustainability}

Many challenges were complex and structured in ways that required joint strategic planning to solve them, calling for leadership and initiative. However, pedagogical initiatives occurred randomly and systematic planning of how to implement ESE in practice did not seem to be an established routine among the preschool teachers. Critical knowledge capability among the visiting Pedagogical Inspiration staff to provide leadership also was not always evident.

It was a shame that it was school holidays, and many were away when the PI team arrived, was a comment by the main responsible preschool teacher, one of three in the 'Outdoor group.' This preschool teacher summed up at the end of the day, while she and the researcher (the only two persons remaining outside) were tidying up, gathering bags, plants and tools bringing everything to be locked into containers and in the building (field notes, Autumn 2018).

The preschool teacher invited some kids to water the plants and berry bushes in one of the soil beds, which was not easy, since water was only available indoors, and it took time to fill cans and carry out to the new plants (field notes, Autumn 2018).

After a delay in the subsequent weeks, a tube and a water pump were also installed in the ecosystem. The staff later told the researcher that the activities for experiencing and exploring and new features of the outdoor space were much appreciated by the children. The lack of coordination in the installation of the 'ecosystem' and water pump was not intentional, but rather reflected the difficulties in communicating both across and within institutions. It was also noticeable that during staff meetings and planning meetings, any intended learning outcomes for the children from these activities were not explicitly articulated (see Thulin 2015).

\section{Reaching Beyond the Outdoor Space}

In this context, alongside sharing activities, the photographs became a language for building bridges (Magnusson 2017). In the preschool teachers' and the researcher's conversations with the children about their 'picture stories,' the children developed more confidence in expressing themselves in Swedish with the adults. The shared experiences underlying their photographs thus offered opportunities to children for expressing their experiences and the meanings they gave to different elements in this space (Einarsdóttir 2005; Cele 2006; Green 2012; Little and Derr 2018; Sobel 2020). The process of taking pictures, telling stories about them and displaying the 
pictures on the indoor walls, engaged many of the children and staff who had not taken part in the work on the outdoor place (cf. Stephenson 2002) and which both children and staff were excited about. These pictures were used in memory books made by the children, which parents then discussed with their children.

The more active role that the preschool staff played in working with storytelling and the memory books, and the continuity of this work reflected that teachers felt more comfortable with language-oriented and indoor activities. Also, while the outdoor group was an ad hoc collaboration across different sections of the preschool, within each section teachers were working within their regular teams, where they could coordinate and plan activities during their staff meetings.

\section{Discussion}

Preschool outdoor spaces can have numerous functions beyond providing opportunities for children's learning about the natural world. Considering that city spaces can be perceived as unsafe and that living conditions may be cramped, encouraging outdoor physical activity is an important goal. The outdoor spaces of a preschool are visible to visitors, and in some sense, they are a more public part of the preschool that should be presentable or offer opportunities to represent symbolic values and status for the preschool as a whole. As a shared and larger space for the preschool, it can offer opportunities for joint celebrations. Finally, it can be seen as a 'free' space outside the more regulated and scheduled indoor spaces in which children are taught in structured ways, offering opportunities for free play and interaction. The ambition of creating space for ESE was thus just one of many-sometimes conflicting-visions. Such perceptions were expressed by the adults during the collective design process and also represented ways in which the space was used in this period. The children expressed enjoyment of learning, discovering and satisfying curiosity, as well as enjoyment of play and sharing in activities.

The conditions at the preschool were in most respects typical of Swedish urban preschools that do not already have an outdoor or environmental profile. Several of the observed obstacles to redesigning the outdoor space and to fully using its potential are therefore likely to be encountered elsewhere. Sobel (2020) has stressed the significance of having adults who can inspire children with their knowledge, experience and enthusiasm for nature. At this preschool, most of the adults were favourable to the idea of a greener outdoor space, but were unsure of how to go about this work or what experiences they could share. As illustrated in these situations, the experts from Pedagogical Inspiration saw their role as helping with supplying appropriate materials (the larkwood box and its contents), rather than as inspiring or supporting educational development (cf. Barratt and Hacking 2011). Implementing these new developments required extensive coordination and time for planning. Management struggled to fit extra meeting time into the staff schedules, but it was still not enough to fully benefit from the potential to actively engage the children and their parents. Nevertheless, as the analysed situations also illustrated, the processes encouraged action, reflection and collaboration across the preschool. Engagement in the process of changing the immediate 
environment would appear to be particularly important for the newly arrived children, as a way of making their own place in Sweden (Little and Derr 2018).

Among the constraints observed in the situations discussed was the inability of the preschool teachers to engage with the children's own questions and initiatives (Thulin 2015) concerning natural phenomena. The findings in this study suggested that preschool staff did not feel confident when it comes to environmental and outdoor education. Very little time was spent addressing environmental science topics or promoting ecological literacy. Trying to infuse outdoor/environmental education could be described as a 'patchwork' approach rather than as a concrete plan that appeared difficult to achieve under the existing conditions (Puk and Behm 2003).

Even though it is an overarching goal in Swedish education, sustainability education is not clearly prioritised by preschool leadership in the context of receiving newcomers. The priorities summarised on the website of Pedagogical Inspiration, the municipality's department for educational development, include equal opportunities for all children, regardless of background, but sustainability is not mentioned. Also, the more specific requirements in the curriculum for the preschool concern scientific literacy (cf. fact-based teaching, Öhman 2008), rather than ESE. Besides the risk of fragmented learning objectives, the focus on scientific literacy downplays social dimensions of sustainability (see Björneloo 2007), as well as the democratic and action-oriented aspects (Öhman 2008; Hedefalk 2014). However, the preschool leader supported and enabled the project of redesigning the outdoor space, investments were made, and the preschool drew on various municipal initiatives to enable experiences with nature. If learning and teaching opportunities were missed, it seemed rather to result from lack of training in how to work with ESE in practice, lack of time for planning and a lack of a shared pedagogical vision. Factors such as staff turnover and replacements also reduced the abilities of the staff to function as a coordinated team.

From a participatory perspective, the final design of an outdoor environment is less important than the extent to which children are able to participate in the design and define what they themselves feel is meaningful (Heft and Chawla 2006; Bergsten and Larberg 2012). However, this perspective is not always compatible with pedagogical stances that focus on immediate learning outcomes, rather than on the conditions for shaping children's active engagement in the world. Just as there is a certain tension between the ambition of 'teaching' to impart knowledge to learners and the recognition of children's engagement, there is an inherent tension between the ambition of PAR to support children's, teachers' and parents' own visions, and the normative agenda of education for sustainability. As researchers, we also struggled to define our stance between simply acting as facilitators in creating spaces for self-reflective discussions, being positioned as 'experts,' or taking part in the processes on an equal footing with other participants. During the process, continuous discussions among children, staff, leadership and researchers made it possible to deal with such tensions and become aware of each other's expectations, situations and visions. 


\section{Conclusions}

This study used a participatory approach, and stress was placed on relevance and meaning for those involved. In this research, the researchers were not positioned as outside neutral observers but were actively involved in the development process. Trustworthiness cannot be fully established in the sense that findings are based on participants' perspectives and highly contextualised. Efforts have been made to present sufficiently detailed descriptions so that others can evaluate which aspects of the findings may be transferable to other contexts.

Preschool offers a wealth of opportunities to actively engage children and parents in a process of wonder, paying close attention to the living world around us and developing the skills to care for it (Sobel 2020). However, deeper awareness and confidence in practical ways for staff in preschool is required to implement ESE. Diverse pedagogical approaches have been developed in this field and sometimes contradictory strategies are proposed. Concrete information is needed on how to tackle constraints and obstacles in ESE that preschool educators encounter in their daily work (Änggård 2010).

A joint frame of reference on pedagogical practices and processes for reflection is needed in which regular dedicated time is available within, and across, early childhood institutions. This requires educators to sit together and discuss these issues. Educators could share thoughts and insights and gain more concrete knowledge about the environment and sustainability in practice. However, available planning time is barely sufficient to deal with the most urgent daily issues so that falling back on existing routines can become the easiest way of coping. Staff turnover is a major obstacle to developing coherent pedagogical visions within preschools. PAR is a powerful approach, but builds on pre-existing awareness and motivation to tackle challenges and refine existing practices. Therefore, unless ESE is understood by a majority of those working in a preschool to be an urgent concern, the potential of PAR processes will also be underutilised. In such cases, an alternative would be to consistently invest in continuous training (Meier and Sisk-Hilton 2017), involving groups of staff and including preschool leadership, rather than expecting individuals to be able to transfer what they have learnt to others in their contexts. Such decisions are ultimately a matter of policy and political will, to make investments in preschools that support ambitions for environmental and sustainability education to be realised and to meet commitments nationally and internationally.

Acknowledgements The study was supported by the Swedish Institute for Educational Research.

Author contributions $\mathrm{BN}$ is the lead author of the manuscript. Each author has contributed equally to manuscript development.

Funding Open Access funding provided by Malmö University. This work was supported by the Swedish Institute for Educational Research and the Region Scania Environmental Fund.

The study was approved by regional Ethics Board at the Swedish Ethical Review Authority. 


\section{Compliance with Ethical Standards}

Conflict of interest The authors do not have any conflict of interest in relation to this work.

Open Access This article is licensed under a Creative Commons Attribution 4.0 International License, which permits use, sharing, adaptation, distribution and reproduction in any medium or format, as long as you give appropriate credit to the original author(s) and the source, provide a link to the Creative Commons licence, and indicate if changes were made. The images or other third party material in this article are included in the article's Creative Commons licence, unless indicated otherwise in a credit line to the material. If material is not included in the article's Creative Commons licence and your intended use is not permitted by statutory regulation or exceeds the permitted use, you will need to obtain permission directly from the copyright holder. To view a copy of this licence, visit http://creativecommons.org/licen ses/by/4.0/.

\section{References}

Andersson, K., \& Gullberg, A. (2014). What is science in preschool and what do teachers have to know to empower children? Cultural Studies of Science Education, 9(2), 275-296.

Änggård, E. (2010). Making use of 'nature' in an outdoor preschool: Classroom, home, and fairyland. Children, Youth and Environments, 20(1), 4-24.

Askerlund, P., \& Almers, E. (2016). Forest gardens-new opportunities for urban children to understand and develop relationships with other organisms. Urban Forestry and Urban Greening, 20(1), 187-197.

Barratt, R., \& Hacking, E. B. (2011). Place-based education and practice: observations from the field. Children, Youth and Environments, 21(1), 1-13.

Bergsten, J., \& Larberg, V. (2012). Children need space: The child's perspective-allowing children to participate in the urban planning process. Tryggare och mänskligare Göteborg [City of Gothenburg's Central Crime Prevention Council]. Göteborg: City of Gothenburg.

Björneloo, I. (2007). Innebörder av hållbar utveckling: En studie av lärares utsagor om undervisning. [Meaning of sustainable development: A study of teachers' statements on teaching]. Ph.D. Dissertation. Göteborg: Acta Universitatis Gothoburgensis.

Blundell, D. (2016). Rethinking children's places and spaces. New York, NY: Bloomsbury Academic.

Caiman, C., \& Lundegard, I. (2014). Pre-school children's agency in learning for sustainable development. Environmental Education Research, 20(4), 437-459.

Cele, S. (2006). Communicating place: Methods for understanding children's experience of place. Solna: Stockholm University.

Christensen, P. H. (2004). Children's participation in ethnographic research: Issues of power and representation. Children and Society, 18(2), 165-176.

Einarsdóttir, J. (2005). Playschool in pictures: Children's photographs as a research method. Early Child Development and Care, 175(6), 523-541.

Flewitt, R. (2005). Conducting research with young children: Some ethical considerations. Early Child Development and Care, 175(6), 553-565.

Frisch, J. K., Unwin, M. M., \& Saunders, G. W. (2010). Name that plant! Overcoming plant blindness and developing a sense of place using science and environmental education. In A. M. Bodzin, B. Shiner Klein, \& S. Weaver (Eds.), The inclusion of environmental education in science teacher education (pp. 143-157). Dordrecht: Springer.

Green, C. (2012). Listening to children: Exploring intuitive strategies and interactive methods in a study of children's special places. International Journal of Early Childhood, 44(3), 269-285.

Hackett, A., Procter, L., \& Seymour, J. (Eds.). (2017). Children's spatialities. Embodiment, emotions and agency. New York: Palgrave Macmillan.

Hammarsten, M., Askerlund, P., Almers, E., Avery, H., \& Samuelsson, T. (2019). Developing ecological literacy in a forest garden: children's perspectives. Journal of Adventure Education and Outdoor Learning, 19(3), 227-241. 
Hansson, L., Löfgren, L., \& Pendrill, A-M. (2014). Att utgå från frågor och situationer i förskolans vardag: Vilket naturvetenskapligt innehåll kan det leda till? [Starting with questions and situations in preschool daily life: What science content can it lead to?] NorDiNa 10(1), 77-89.

Hedefalk, M. (2014). Förskola för hållbar utveckling. Förutsättningar för barns utveckling av handlingskompetens för hållbar utveckling. [Preschool for sustainable development. Conditions for children to develop action competence for sustainable development]. PhD Dissertation, Faculty of Educational Sciences 3. Uppsala: Acta Universitatis Upsaliensis.

Heft, H., \& Chawla, L. (2006). Children as agents in sustainable development: the ecology of competence. In C. Spencer \& M. Blades (Eds.), Children and their environments-learning, using and designing spaces (pp. 199-216). Cambridge: University Press.

James, A., \& Prout, A. (Eds.). (1997). Constructing and reconstructing childhood: New directions in the sociological study of childhood. London: Falmer.

Jansson, M., \& Mårtensson, F. (2012). Green school grounds: A collaborative development and research project in Malmoe, Sweden. Children, Youth and Environments, 22(1), 260-269.

Jansson, M., Gunnarsson, A., Mårtensson, F., \& Andersson, S. (2014). Children's perspectives on vegetation establishment: Implications for school ground greening. Urban Forestry and Urban Greening, 13(1), 166-174.

Jordt Jørgensen, N., Dahl Madsen, K., \& Læssøe, J. (2018). Waste in education: The potential of materiality and practice. Environmental Education Research, 24(6), 807-817.

Jordt Jørgensen, N., \& Martiny-Bruun, A. (2019). Painting trees in the wind: Socio-material ambiguity and sustainability politics in early childhood pedagogies with refugee children in Denmark. Environmental Education Research. https://doi.org/10.1080/13504622.2019.1602755.

Little, S., \& Derr, V., et al. (2018). The influence of nature on a child's development: Connecting the outcomes of human attachment and place attachment. In A. Cutter-Mackenzie (Ed.), Research handbook on childhoodnature (pp. 1-27). Switzerland: Springer International Handbooks of Education.

Lpfö 98 (2018). Swedish national curriculum for the preschool, revised 2016; 2018. Stockholm: Ministry of Education.

Kemmis, S. (2009). Action research as a practice-based practice. Educational Action Research, 17(3), 463-474.

Kemmis, S., Wilkinson, J., Edwards-Groves, C., Hardy, I., Grootenboer, P., \& Bristol, L. (2014). Changing practices, changing education. London: Springer.

Knight, S. (2009). Forest schools and outdoor learning in the early years. London: Sage Publications.

MacQuarrie, S., Nugent, C., \& Warden, C. (2015). Learning with nature and learning from others: nature as setting and resource for early childhood education. Journal of Adventure Education and Outdoor Learning, 15(1), 1-23.

Magnusson, L. O. (2017). Treåringar, kameror och förskola: En serie diffraktiva rörelser. [Three-year olds, cameras and preschool: A series of diffractive movements]. Ph.D. Dissertation. Gothenburg: Gothenburg University.

Meier, D., \& Sisk-Hilton, S. (2017). Nature and environmental education in early childhood. The New Educator, 13(3), 191-194.

Nordén, B. (2016). Learning and teaching sustainable development in global-local contexts. Malmö högskola. PhD Dissertation. Malmö: Malmö University. http://muep.mau.se/bitstream/handl e/2043/20501/2043_20501_Nord\%E9n2.pdf?sequence=2\&isAllowed=y. Accessed 1 March 2020.

Öhman, J. (2008). Environmental ethics and democratic responsibility: A pluralistic approach to ESD. In J. Öhman (Ed.), Values and Democracy in education for sustainable development: Contributions from Swedish research (pp. 17-32). Malmö: Liber.

Pedersen, H. (2019). The contested space of animals in education: A Response to the "animal turn" in education for sustainable development. Education Sciences, 9(3), 211.

Pramling Samuelsson, I. (2017). Utvecklingspedagogik—ett sätt att arbeta både målmedvetet och med barns perspektiv [Developmental pedagogy—a way to work both with objectives and children's perspective)]. In B. Riddersporre \& S. Persson (Eds.), Utbildningsvetenskap för förskolan [Pedagogy for preschool] (pp. 91-106). Stockholm: Natur and Kultur.

Puk, T., \& Behm, D. (2003). The diluted curriculum: the role of government in developing ecological literacy as the first imperative in Ontario secondary schools. Canadian Journal of Environmental Education, 8(1), 217-232. 
Sanders, M. G. (2003). Community involvement in schools - from concept to practice. Education and Urban Society, 35(2), 161-180.

Schiller, W., \& Einarsdottir, J. (2009). Listening to young children's voices in research-changing perspectives/changing relationships. Early Child Development and Care, 179(2), 125-130.

SNAE (2017). Skolverkets allmänna råd med kommentarer: Måluppfyllelse i förskolan. [Swedish National Agency for Education general recommendations with comments: Attaining targets in preschool]. Stockholm: Fritzes.

Smith, G. A. (2002). Place-based education: Learning to be where we are. Phi Delta Kappa, 83(8), 584-594.

Sobel, D. (2020). Foreword. In D. R. Meier \& S. Sisk-Hilton (Eds.), Nature Education with Young children integrating inquiry and practice (pp. xiii-xvi; 2nd edn). New York: Routledge.

Spannring, R. (2017). Animals in environmental education research. Environmental Education Research, 23(1), 63-74.

Stephenson, A. (2002). Opening up the outdoors: Exploring the relationship between the indoor and outdoor environments of a centre. European Early Childhood Education Research Journal, 10(1), 29-38.

Swedish Research Council CODEX [n.d.]. Vetenskapsrådet (u.å.). Forskningsetiska principer inom humanistisk-samhällsvetenskaplig forskning [Rules and Guidelines for Research in the Humanities and Social Sciences]. Accessed March 1st, 2020 at www.codex.vr.se/en/index.shtml.

Thulin, S. (2015). Göra naturvetenskap i förskolan—med fokus på kommunikation [Doing science at preschool-focus on communication]. Stockholm: Liber.

Tuck, E., \& McKenzie, M. (2015). Theory, methodology, and methods. Abingdon and New York: Routledge.

Wells, N. M. (2014). The role of nature in children's resilience: Cognitive and social processes. In K. G. Tidball \& M. E. Krasny (Eds.), Greening in the red zone: Disaster, resilience and community greening (pp. 95-109). Dordrecht: Springer.

Woodhouse, J. L., \& Knapp, C. (2000). Place-based curriculum and instruction: Outdoor and environmental education approaches. Charleston, WV: ERIC Clearinghouse on Rural Education and Small Schools.

Publisher's Note Springer Nature remains neutral with regard to jurisdictional claims in published maps and institutional affiliations.

Birgitta Nordén is a senior lecturer and researcher in educational sciences and science education at the Faculty of Education and Society, Department of Science, Mathematics and Society, University of Malmö. With a background in science education and as director of distance education, she has specialised in transdisciplinary teaching, global learning towards sustainability, and environmental and sustainability education (ESE) for the past 30 years. Research interests include global learning for sustainable development (GLSD) with deep approaches to digital learning and teaching in transnational and local contexts, issues related to critical knowledge capabilities, as well as transformative formal and nonformal learning. Birgitta Nordén is the lead author of the manuscript.

Helen Avery is a researcher at the Centre for Middle Eastern Studies and Centre for Environmental and Climate Research, Lund University, and at Linné University. Her current work concerns future-oriented methodologies for sustainability transitions and research interests include sustainable society-building, transdisciplinary research environments, as well as issues linked to refugee education in Sweden and globally. 